\title{
Mechanism of Commercialization of Innovative Technologies in the Agroindustrial Sector
}

\author{
Tkalenko Nataliia, Shestakovska Tetiana, Zelisko Inna
}

\begin{abstract}
In today's highly competitive, dynamic and volatile conditions, the agroindustrial sector is able to successfully operate in the market and take leadership positions to a large extent by developing and commercializing innovations. The purpose of the article is to study the scientific and applied principles of the development of commercialization of innovations in the agrarian sector in Ukraine as a direction of support of its leadership positions in the world market of agrarian products. As a result of theoretical generalization and comparison of the leading scholars' views, the own approach has been substantiated to determine the content of the commercialization of innovations. Through systematic analysis, the current state of innovation activity in the agroindustrial sector is analyzed and the tasks important for the present day are necessary to ensure the process of commercialization of innovations. The prospect of changing the relationship between of higher education sectors, agroindustrial sector, the government sector and the civil society sector as the elements of the Quadruple Helix model are substantiated. The forms and methods for the commercialization of innovations in the agrarian sector have been identified on the basis of the use of strategic and structural-functional analysis methods. The conceptual approach to the formation of the mechanism of commercialization of innovative technologies in the agrarian sector of Ukraine is proposed, the typical stages of implementation of the mechanism are determined. The necessity of improving the infrastructure of the scientific and educational sphere in the direction of commercialization of innovations in the agro-industrial sector is substantiated.
\end{abstract}

Keywords: commercialization; agrarian sector; innovative technologies; mechanism; Quadruple Helix model; commercialization center.

\section{INTRODUCTION}

In the current context, the agrarian sector demonstrates the necessity of an increase in a range of products, improvement of the consumer parameters of products, technical and technological modernization, development of the control systems, search for innovative solutions to ensure leadership qualities, etc. Such transformations are aimed primarily at cost optimization, better satisfaction of consumers' needs,

Revised Manuscript Received on November 15, 2019

* Correspondence Author

Tkalenko Nataliia, ,Doctor of Economic Sciences, Professor, Chernihiv National University of Technology, Chernihiv, Ukraine ORCID ID 0000-0003-2828-4896, Resecher ID F-7638-2016

E-mail: tnv2504@gmail.com, Tel:+380503131674

Shestakovska Tetiana, Candidate of Economic Sciences, Senior Lecturer, Chernihiv National University of Technology, Chernihiv, Ukraine ORCID ID 0000-0002-8098-8439, Resecher ID G-8563-2014

E-mail: Shestakovska27@gmail.com, Tel:+380632529629

Zelisko Inna, ,Doctor in Economic Sciences, Professor, Academician of the Academy of Economic Sciences of Ukraine,

Professor of Management Department, State University of Telecommunications, Ukraine ORCID ID: 0000-0002-0803-2598

E-mail: innazelisko23@gmail.com , Tel:+380679019004 stabilization of financial condition, formation of competitive advantages, maintenance of market positions. In such conditions, there is a need to implement effective commercialization of innovations in the agrarian sector on the basis of the use of the most effective forms and methods taking into account the needs for increasing the leadership positions in the market environment.

It should be noted that the position of Ukrainian scholars regarding the process of commercialization is similar. All authors support the idea that the main purpose of the commercialization process is to generate profits or other economic benefits. Furthermore, most scientists believe that commercialization is a set of certain actions and relationships in the process of transformation of scientific research into goods. The development of entrepreneurship in such conditions faces a number of challenges, first of all, changing the factors of competitiveness of economic entities. The high competitive positions require innovation activity, flexibility and adaptability of enterprises to the changes of dynamical economic environment.

Foreign authors such as G.D. Markman, D.S. Siegel, M. Wright, consider the commercialization process as a particular ecosystem, which is a market and includes a set of components involved in the process of commercialization [1]. A.P. McCoy, R. Badinelli, K.T. Koebel, W. Thabet, agrees that the process of commercialization is a process of making of decisions and appropriate actions for the transformation of an innovative product from an idea to the market [2]. The authors point out that the process of commercialization often concerns the development of a new product, but not its expansion.

In the context of innovation activity of scientific and educational institutions, A. B. Pushkarenko treats commercialization as a modernization of the results of research work in relation to a particular consumer in order to bring them to the market. The author states that the creation of innovations does not necessarily involve the receipt of a commercial product at once. This requires the involvement of a third party professionally engaged in the commercialization of innovations [3].

We have distinguished three contradictions regarding the views on the commercialization process and its economic affiliation. The first contradiction is that the purpose of the commercialization is to sale innovations, but not to create innovations demanded by the market. As a result, we can see a secondary importance of demand for innovation in accordance with its proposal. The second contradiction is that commercialization does not have a significant impact on the development of a market economy because it is mainly at the micro level. 
The third contradiction is that commercialization is regarded as a static process, but it is a dynamic one [4].

Professor, V. Bazilevich the commercialization of research results understands as the process of their involvement in economic circulation through the sale of exclusive property rights of intellectual property on a contractual basis [5]. This approach to the interpretation of the essence of the analyzed term seems to us the most sensible in economic context of our research; we share it and lay in the foundation of our study.

Multidimensionality of this category requires the conduct of multidisciplinary research, the integration of different scientific approaches. It has been proposed to consider the commercialization of innovations in the agrarian sector as a process of introducing them to the market in order to obtain socio-economic benefits and to strengthen leadership positions.

\section{MATERIALS AND METHODS}

In the course of the research, general scientific and special research methods have been used, in particular: theoretical generalization, comparison and morphological analysis - in the process of formation of the conceptual-categorical apparatus of research; system analysis - for identification of opportunities and justification of the results of the functioning of the agrarian sector of Ukraine which take leadership positions in the commercialization of innovation; strategic and structural-functional analysis - for formation of conceptual principles for construction of the components of the mechanism of commercialization of innovative technologies in the agrarian sector.

\section{RESULTS}

The high level of innovation activity of the agrarian enterprises creates the preconditions for forming new competitive advantages, increasing investment attractiveness, expanding opportunities for entering new markets, is an impetus for ensuring progressive development and leadership. The commercialization of innovations in the agrarian sector is a mechanism for turning the results of the intellectual sphere into market products. A large number of both fundamental and applied discoveries remain at the stage of development. The reasons for this situation can be not only lack of funds, but also inability to make commercialization of innovation, technology or ideas properly. Consequently, the significance and necessity of the commercialization process are evident. The realities of the Ukrainian economy are characterized by the uncompromising need to increase the role of innovations as a key factor for the leadership of the agrarian sector in the competitive struggle.

Despite the inevitability of the processes of increasing the dependence of success of the agricultural producers from the innovation of agribusiness, in practice, the pace of production and introduction of innovation remain low in the domestic the agrarian sector. Compared to 1995 , the number of innovative enterprises in the industry declined by $63 \%$. Thus, in 2016, 735 enterprises carried out innovation activities in the agrarian sector (Table 1), which was $16.6 \%$ of the total number of industrial enterprises in Ukraine and $20.8 \%$ of the total number of enterprises that carried out innovative activities. Among them, most enterprises were engaged in such types of innovation activities as the purchase of machinery, equipment, and software $(61.1 \%$ of the total number of innovative enterprises engaged in the of food production); personnel training $(24.4 \%)$; other works $(5.5 \%)$ [6].

Despite the tangible, at first glance, increase in the number of names of innovative products introduced by the enterprises in the field of food products, beverages and tobacco products, the share of such products in the total volume of industrial innovative products decreased. In addition, in 2017, new machinery, equipment, apparatus, and devices did not exceed $3.6 \%$ of the total volume of innovative products. Furthermore, they were not fundamentally new one for the market at all, which is unacceptable, given the state of deterioration of agricultural machinery in Ukraine [7].

Innovative activity in the field of distribution of agro products is even lower than directly in the field of agrarian production. During 2010-2017, the number of agrarian enterprises that sold innovative products and their share in the total number of all industrial enterprises decreased. Similarly, the number of enterprises that sold innovative products outside Ukraine and the volumes of such products went down. At the same time, as of 2017 , only $15.9 \%$ of enterprises in the field of production of food products, beverages and tobacco products sold innovative products that were new to the specific market, the remaining $84.1 \%$ of products were new exclusively for the enterprise. The reasons for the low innovation activity of Ukrainian agribusiness are the technological backwardness of agriculture and the agrarian sector. Despite the fact that nowadays developed countries of the world are developing genetic engineering techniques in breeding, creating opportunities for the functioning of cellular structures of plants and animals, and introducing high-tech systems for regulating growth and development of plants based on the principles of precision farming and nanotechnologies, during 2010-2014 it has not been created any fundamentally new high technology in Ukrainian agriculture. For the food industry, the figures are more persuasive (15 fundamentally new technologies for 2010-2014), but during the period under review, there is a negative dynamics of the indicator. The number of high technologies used in agriculture on the basis of available statistical data did not exceed two dozen per year. More active use of new high technologies took place in the field of food products, beverages and tobacco products, but the share of high technologies with a term of introduction up to 1 year decreased from 14 to $5 \%$ [7].

\section{DISCUSSION}

To implement the commercialization of innovations in the agrarian sector, it is necessary to have information about all its possible forms and methods. Based on the analysis of available resources and the set of goals in innovation activities, the agrarian enterprise chooses an optimal form and method of commercialization of innovations. In case of successful selection, the maximum benefit is obtained for the functioning and development of the agrarian sector.

The forms of commercialization of innovations in the agrarian sector can be commercialization carried out independently by an enterprise producing innovative products, outsourcing, and its combination. 
Under self-commercialization, an enterprise does not always have all the necessary resource support. In this case, the enterprise needs to attract resources from external sources (investors, sponsors, lenders, the state, etc.). In case of reluctance or impossibility of the enterprise to make commercialization independently, it can involve another enterprise that will carry out the process of commercialization professionally. A combined form provides that the enterprise producing innovative products can partially make commercialization by itself, partly through another enterprise (for instance, for commercialization in the domestic and foreign markets).

However, in order to make commercialization of innovation successfully in accordance with the goals and opportunities of the agrarian sector, it is necessary to choose the best form and methods. The form of self-realization of the commercialization of innovative products provides the following methods: use at the enterprise, establishment of a subsidiary and sale of a patent. In this form, these methods are most rational, because the enterprise is expedient and realistic to carry out all of the above-mentioned on its own.

In the framework of the outsourcing commercialization form, it is possible to select a method with a complete commercialization cycle and an incomplete commercialization cycle. The difference in these methods is the number of enterprises involved in commercialization. If one external enterprise can provide all stages of commercialization and the developer satisfies the quality of the services provided, the external enterprise uses the complete cycle commercialization method. In case the developer wants to choose different providers of commercialization for different stages, then the incomplete commercialization cycle method is used [8].

The following issues should be considered in the economic problems of commercialization of innovative technologies in the agrarian sector: difficulties with the accounting of patents and other security documents created for the budget funds; the lack of an effective legal mechanism for funding university innovative projects; the need for professional training of specialists in innovative management, protection of intellectual property rights, technology transfer, marketing and commercialization of the research results in industry, etc. Particular attention is to be paid to the problem of the existence of gaps between the subjects of higher education sector, agrarian sector, government sector and civil society (based on the Quadruple Helix model).The mentioned gap could be minimized by implementing the mechanism of commercialization of innovative technologies in the agrarian sector. In [Figure-1].

In our opinion, the main functional elements of the mechanism of commercialization of innovative technologies in the agrarian sector are the following: 1) resource management; 2) legal protection of the research results as objects of intellectual property; 3 ) promotion of the research results to the market; 4) information support; 5) strategic planning of the development of the agrarian sector.

In agriculture and agro-industries, activities that only with a certain degree of conventionality can be attributed to innovation (acquisition of new machines and equipment, marketing research, training of personnel) are prevalent. There are serious problems in establishing an effective interaction of the entrepreneurial sector with the branch, academic and university sectors of agrarian science, which require a more detailed study. The commercialization of innovations in the agrarian sector is not possible without the existence of a powerful source of new ideas and technologies for agribusiness. In the developed countries, the scientific and educational institutions that are generators of ideas and applied developments for enterprises of the real economy are the basis of the national innovation systems. The integration of Ukraine into the European political, social and economic space and the consolidation of the leading exporter's position in the world food markets sharply update the need for the development of the domestic system of agrarian education and support of scientific research in order to provide the agrarian sector with modern innovative technologies and competitive staff [8-9].

That is, the commercialization of innovations is an effective mechanism for interaction between institutions of higher education, scientific and research, project and research enterprises, individual scientists interested in the practical application of their scientific developments and projects both on the territory of Ukraine and abroad. The selection of potential customers (partners) of the commercialization of innovations is based on the analysis of information from various sources: specialized databases, publications, booklets, advertising materials, evaluations of authoritative experts, etc. Particular importance for the successful promotion of innovation is the availability of a database for relevant relations and support for developers` research results from the state.The Ministry of Education and Science of Ukraine as an authorized central body of executive power in the field of technology transfer and the Academy of Technological Sciences of Ukraine signed an Agreement on Cooperation in the field of Technology Transfer in 2018. During the duration of this Treaty, the Academy developed the conceptual foundations and methodological principles for the establishment of the National Technology Transfer Network, which were the basis for the functioning and operational model of the pilot project - the Ukrainian Technology Transfer Network (UTTN) and its segments.

The technology transfer network existing in Ukraine, in the name of their coordinators or networks, created on the initiative of the national coordinator or the subjects of innovation activity, can join the national technology transfer network on the rights of its segment. To join the national technology transfer network, a potential participant applies to the national coordinator and establishes a contractual relationship with him. The participants of the national network are required to be certified for compliance with the network requirements in accordance with the Regulation, which is approved by the national coordinator.

To ensure the efficiency of the commercialization of innovations generated by the scientific and educational sector, we propose to establish appropriate centers of commercialization, as an organization or a structural unit which activities are aimed at generating revenue from the use of innovations. The main mission of the Center is determination of the feasibility of the commercialization of innovations, assistance in the formulation of rights to selected innovations for commercialization, conclusion of license agreements for transfer of property rights, promotion of establishment of start-up companies, fair distribution of royalties between authors of research results, the units in 
which they work, the scientific and educational institutions. The partners of the Center can be the research sectors of higher education institutions, industrial parks, and science parks, as well as startup companies and structural units related to the commercialization of innovations. Potential licensees, created startups, small business representatives, etc. can be potential customers. Science parks and industrial parks related to a higher education institution, patent-licensing departments, and research sectors can be both partners and competitors.

\section{CONCLUSION}

New ideas, developments that can be turned into innovations and their successful commercialization increasingly determine the competitiveness and leadership of the agrarian sector in the world. As practice shows, only a small part of innovation is transformed into innovative products and is successfully commercialized through its promotion to interested consumer groups. The implementation of innovations and research results into the real sector of national economy is capable of ensuring the country's innovative development and raising its competitiveness at the global level.

The authors identify the key stages of realization of the mechanism of commercialization of innovative technologies in the agrarian sector in Ukraine: 1) identification of perspective directions of innovation, scientific and technical activities; 2) planning of research activities; creation of commercially attractive, competitive in the market of innovative, scientific and technical products; 3) management in agrarian sector with the focus on the implementation and commercialization of research results; 4) the protection of intellectual property rights to the research results of the HEIs registered at the patent offices; 5) obtaining economic and social effects from the commercialization of innovative technologies in the agrarian sector.

Taking into account the peculiarities of the functioning of the model of the organization of the scientific and educational process, and market economy, the activity of complex centers, which together with the transfer of technologies, would deal with issues that cover the entire commercialization process (from the formation of an innovative idea to its promotion to the market: development of the strategies for using innovations, acquiring rights to research results, other issues of the life cycle of innovative products) will be relevant for Ukraine. One of the effective models for the commercialization of innovations in the agrarian sector can be start-up or spin-off companies created on the basis of the scientific and educational sector. Their main task is to bring innovations to a state suitable for use in industry. Among the promising directions of the development of the commercialization of innovations is the formation of commercialization centers, which are a newly created organization or a structural unit in the scientific and educational institutions, which activity is focused on getting income from the use of innovations in the agrarian sector.

The prospects for the further research are to study the best practices of world universities in the commercialization of the innovative technologies in the agrarian sector with a view to its further adaptation to the domestic socio-economic realities.

\section{REFERENCES}

1. Gideon D., Markman, Donald S. Siegel, Mike Wright (2008) Markman Research and Technology Commercialization. Journal of Management Studies. 45:8:1401-1423.

2. McCoy A. (2008) Concurrent Commercialization and New-Product Adoption for Construction Products. «The construction and building research conference of the Royal Institution of Chartered Surveyors» COBRA 2008). Dr. Ralph Badinelli, Dr. C. Theodore Koebel, Dr. Walid Thabet. Dublin Institute of Technology, Dublin, 4:5.

3. Pushkarenko A.B. (2004) Commercialization of scientific and technical developments as a constituent element of the innovation activities of scientific and educational institutions. Bulletin of the Tomsk Polytechnic University. 3: 137-141.

4. Bogolib T.M. (2014) Commercialization of scientific elaborations of universities. Ukraine`s economy. №. 1 (618). P. 33-50.

5. Bazilevich V.D. (2014) Intellectual Property: [Tutorial] / VD Bazilevich; 3rd issue, reworked. and complemented K.: Knowledge, 671.

6. Capital investment in agriculture in 2017 see Ministry of Agrarian Policy and Food of Ukraine 2018 available at: URL: http:// http://www.minagro.gov.ua/en/node/25504

7. Statistical information: innovative activity. State Service of Statistics of Ukraine. URL: http: //www.ukrstat.go.u.

8. Mazur I. (2013) Commercialization of scientific developments as a factor of competitive development of entrepreneurship. Bulletin of Taras Shevchenko National University of Kyiv. No. 148. P.245-251.

9. Kholiavko N. (2018) Theoretical and Applied Aspects of Commercialization of Research Results in the Conditions of Information Economics. Ukraine - EU. Innovations in Education, Technology, Business and Law: collection of international scientific papers. Chernihiv: CNUT, 169-172

\section{AUTHORS PROFILE}

Tkalenko Nataliia ,Doctor of Economic Sciences, Professor, Chernihiv National University of Technology, Chernihiv, Ukraine ORCID ID 0000-0003-2828-4896, Resecher ID F-7638-2016

E-mail:tnv2504@gmail.com, Tel:+380503131674

Shestakovska Tetiana,Candidate of Economic Sciences, Senior Lecturer, Chernihiv National University of Technology,

Chernihiv, Ukraine ORCID ID 0000-0002-8098-8439, Resecher ID G-8563-2014

E-mail: Shestakovska27@gmail.com,Tel:+380632529629

Zelisko Inna ,Doctor in Economic Sciences, Professor, Academician of the Academy of Economic Sciences of Ukraine,

Professor of Management Department, State University of Telecommunications, Ukraine ORCID ID: 0000-0002-0803-2598

E-mail: innazelisko23@gmail.com,Tel:+380679019004 


\section{Appendix}

\section{Table-1}

\begin{tabular}{|c|c|c|c|c|c|c|}
\hline \multirow{2}{*}{\begin{tabular}{|c|} 
Indicators \\
Years \\
\end{tabular}} & \multirow{2}{*}{$\begin{array}{c}\text { Number of } \\
\text { agrarian } \\
\text { enterprises that } \\
\text { introduced } \\
\text { innovations, units }\end{array}$} & \multirow{2}{*}{$\begin{array}{l}\text { Share of agrarian } \\
\text { enterprises that } \\
\text { introduced } \\
\text { innovations, } \%\end{array}$} & \multirow{2}{*}{$\begin{array}{l}\text { Share of sold } \\
\text { innovative } \\
\text { products in the } \\
\text { volume of } \\
\text { industrial } \\
\text { products, } \%\end{array}$} & \multirow{2}{*}{$\begin{array}{l}\text { Number of } \\
\text { developed } \\
\text { innovative } \\
\text { types of } \\
\text { products, units }\end{array}$} & \multicolumn{2}{|c|}{$\begin{array}{c}\text { Number of introduction of } \\
\text { new technological } \\
\text { processes, units }\end{array}$} \\
\hline & & & & & Total & $\begin{array}{l}\text { Including } \\
\text { low-waste, } \\
\text { resource-saving } \\
\text { processes }\end{array}$ \\
\hline 1995 & 2002 & 22.9 & - & 11472 & 2936 & 1044 \\
\hline 2000 & 1491 & 14.8 & - & 15323 & 1403 & 430 \\
\hline 2001 & 1503 & 14.3 & 6.8 & 19484 & 1421 & 469 \\
\hline 2002 & 1506 & 14.6 & 7.0 & 22847 & 1142 & 430 \\
\hline 2003 & 1120 & 11.5 & 5.6 & 7416 & 1482 & 606 \\
\hline 2004 & 958 & 10.0 & 5.8 & 3977 & 1727 & 645 \\
\hline 2005 & 810 & 8.2 & 6.5 & 3152 & 1808 & 690 \\
\hline 2006 & 999 & 10.0 & 6.7 & 2408 & 1145 & 424 \\
\hline 2007 & 1186 & 11.5 & 6.7 & 2526 & 1419 & 634 \\
\hline 2008 & 1160 & 10.8 & 5.9 & 2466 & 1647 & 680 \\
\hline 2009 & 1180 & 10.7 & 4.8 & 2685 & 1893 & 753 \\
\hline 2010 & 1217 & 11.5 & 3.8 & 2408 & 2043 & 479 \\
\hline 2011 & 1327 & 12.8 & 3.8 & 3238 & 2510 & 517 \\
\hline 2012 & 1371 & 13.6 & 3.3 & 3403 & 2188 & 554 \\
\hline 2013 & 1312 & 13.6 & 3.3 & 3138 & 1576 & 502 \\
\hline 2014 & 1208 & 12.1 & 2.5 & 3661 & 1743 & 447 \\
\hline 2015 & 723 & 15.2 & 1.4 & 3136 & 1217 & 458 \\
\hline 2016 & 735 & 16.6 & - & 4139 & 3489 & 748 \\
\hline 2017 & - & 14.3 & - & 2387 & 1831 & 611 \\
\hline
\end{tabular}

Table:1. Perspectives and results of commercialization of innovations in the agrarian sector of Ukraine Source: [7] 
Figure-1
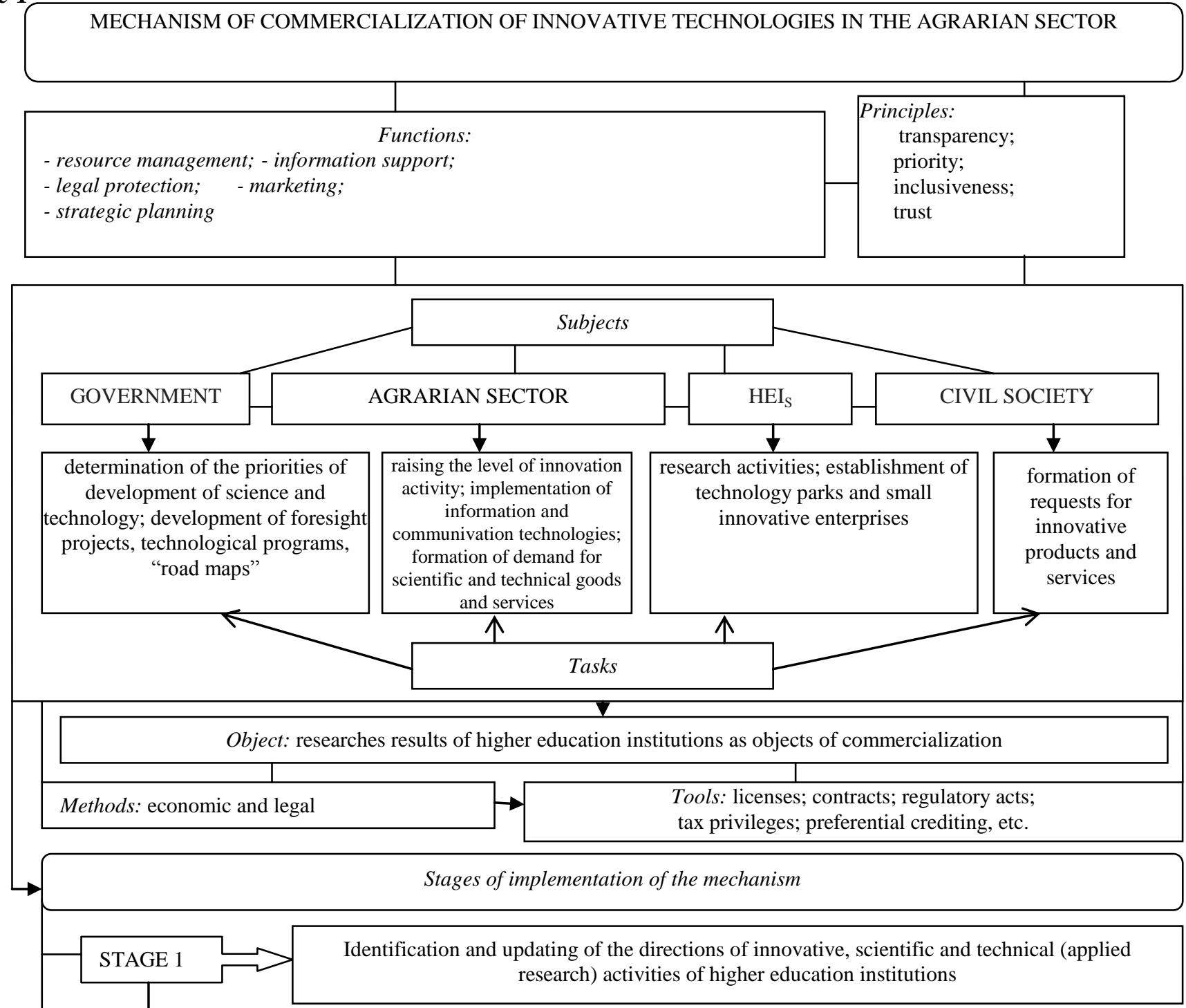

Planning and conducting research; creating scientific products - commercially attractive, competitive on the market

1. Regulation and harmonization of current legislation with EU law

2. Development and implementation of effective tools for tax incentives for economic actors to commercialize research results

3. Formation of an effective legal mechanism for financing innovative projects of higher education institutions.

4. Development of innovation infrastructure

Legal protection of research results of higher education institutions

Obtaining economic and social effects from the commercialization of research results

Strategic benchmarks for the mechanism 